\title{
EPIDEMIOLOGICAL AND CLINICAL PROFILE OF BREAST CANCER PATIENTS AT KR HOSPITAL, MYSORE
}

Rangaswamy1, Vikas $L^{2}$

${ }_{1}^{1}$ Associate Professor, Department of Medicine, Mysore Medical College and Research Institute.

${ }^{2}$ Assistant Professor, Department of Medicine, Mysore Medical College and Research Institute.

ABSTRACT
BACKGROUND
Cancer rates are set to increase at an alarming rate globally to 15 million new cases in the year 2020. Worldwide breast cancer is
the most frequent cancer in women and represents the second leading cause of cancer death among women (after lung cancer).
Presently, 75,000 new cases occur in Indian women every year. Immunological and histological management of breast cancer
requires multidisciplinary treatment. The difference in management of breast cancer under the hands of surgical oncologist and
general surgeons vary and need for aggressive planned neo-adjuvant chemotherapy by medical oncologist is needed.

\section{MATERIALS AND METHODS}

This is a retrospective descriptive study hospital records of 104 patients admitted from October 2013 to October 2016 were used for study and data analysis.

Study Design- A retrospective descriptive study.

\section{RESULTS}

The average mean age of our female breast cancer patients was lower compared to the statistics of western world with at least one to two decades difference. A large percentage of patients were from rural setup and had longer duration of symptoms. Left side lump in the breast was the most common symptom. Screening by mammography and staging procedures such as bone scan, Computed Tomography (CT) scan and Magnetic Resonance Imaging (MRI) were sparsely used. The most common histology was infiltrating ductal carcinoma.

\section{CONCLUSION}

Modified radical mastectomy is considered gold standard in early breast cancer. Infiltrating ductal carcinoma was more commonly associated with positive lymph nodes compared to other histopathologies. Neoadjuvant chemotherapy was used mainly by clinical oncologists suggesting a more rational approach toward the management of breast carcinoma.

\section{KEYWORDS}

Breast Cancer, Combined Modality, Epidemiology, Surgery.

HOW TO CITE THIS ARTICLE: Rangaswamy, Vikas L. Epidemiological and clinical profile of breast cancer patients at KR Hospital, Mysore. J. Evolution Med. Dent. Sci. 2018;7(05):675-678, DOI: 10.14260/jemds/2018/153

\section{BACKGROUND}

Cancer rates are set to increase at an alarming rate globally to 15 million new cases in the year 2020.[1] Worldwide breast cancer is the most frequent cancer in women and represents the second leading cause of cancer death among women (after lung cancer).[2],[3] Presently, 75,000 new cases occur in Indian women every year.[4] Epidemiology of breast cancer in India is very limited. Locally advanced breast cancer (LABC) constitutes more than $50 \%$ to $70 \%$ of the patients presenting for treatment.[4]

Immunological and histological management of breast cancer requires multidisciplinary treatment.[3] The difference in management of breast cancer under the hands of surgical oncologist and general surgeons vary and need for aggressive planned neoadjuvant chemotherapy by medical oncologist is needed. Hence, this retrospective study was carried out to know the epidemiology, clinical presentation, risk factors and management strategies for breast cancer patients.

'Financial or Other Competing Interest': None.

Submission 15-11-2017, Peer Review 12-01-2018,

Acceptance 18-01-2018, Published 29-01-2018.

Corresponding Author:

Dr. Vikas $L$,

\#29, $2^{\text {nd }}$ Main, KGS Layout,

Saraswati Nagar, Bangalore-40.

E-mail: vikilaxman@gmail.com

DOI: $10.14260 /$ jemds $/ 2018 / 153$

\section{MATERIALS AND METHODS}

A total of 104 primary breast cancer patients admitted over a period of 3 years period (October 2013 - October 2016), in KR Hospital, Mysore were taken up for study. Post mastectomy patients outside KR Hospital were excluded. A detailed retrospective descriptive study analysis of patients was done and tabulated. The retrospective descriptive study information was collected from the medical records department in KR Hospital, Mysore.

A majority of the patients (70\%) were in the age group of 31 - 50 years. The youngest patient was 25 and the oldest was 80 years old. Of the 104 patients, $100(98.7 \%)$ were females and four $(1.3 \%)$ were males. The total of $72(70 \%)$ were from rural setup and 32 (30\%) from urban setup with ratio being 1.9: 1 .

[Table 1] shows that $93(90 \%)$ patients presented with a lump in the breast; 47 (55\%) patients had a right breast lump and $32(30 \%)$ had left breast lump. The pattern of presenting complaints were recorded in $102(99.0 \%)$ patients as shown in [Table 2]. 68 (65\%) patients presented with a history of more than three months' duration and only three (2\%) patients presented with a history of less than 15 days history. Of 100 female breast cancer patients, $83(80 \%)$ had less than two children and $16(15 \%)$ were nulliparous. Of this, $16 \%$ of patients were post-menopausal. No patient had a positive family history of breast cancer. 
Fine needle aspiration cytology (FNAC) was done in 86 patients. It was positive for malignancy in 77 (90\%) and negative or inconclusive in $7(10 \%)$ patients. Inconclusive or negative patients were further subjected for excision biopsy. Mammography were done only in 16 (15\%) patients. 5 (5\%) patients were diagnosed to have lung metastasis on a chest $\mathrm{x}$ ray. In 95 (91.4\%) patients an ultrasound of the abdomen was done and $4(4.6 \%)$ were found to have metastasis in the liver. Liver function tests (LFTs) were done in 26 (25\%) patients. Out of these 26 patients $12(45 \%)$ had LABC, 10 $(40 \%)$ had early breast cancer (EBC) and $4(15 \%)$ were stage IV.

The surgical treatment given to the patients are as follows: a total of $100(97 \%)$ patients underwent surgery and remaining $4(3 \%)$ were inoperable cases. Out of 100 operated cases, $80(80 \%)$ underwent modified radical mastectomy (MRM). Out of 100 operated cases $62(62 \%)$ were operated by surgical oncologists, while the remaining were operated by general surgeons. A majority of the patients, 67 (64\%), received anthracycline-based chemotherapy with 56 (54\%) receiving cyclophosphamide, epirubicin and 5-fluorouracil (FEC) respectively. 50 (50\%) patients received hormone therapy and Tamoxifen $20 \mathrm{mg}$ daily.

[Table 3] shows the final histopathology profile of 100 operated patients. 98 (98\%) patients had invasive ductal carcinoma (IDC). Out of 100 cases of axillary dissection, no lymph nodes were isolated from the specimen in $2(2 \%)$ patients. In 21 (20\%) patients 1 - 5 lymph nodes were isolated, in 50 (50\%) 6 - 10 lymph nodes, in 25 (25\%) patients 11 - 15 lymph nodes, in $6(6 \%)$ patients $16-20$ lymph nodes and in 1 (1\%) patient more than 20 lymph nodes were isolated. The final staging of patients with LABC were $60 \%, 35 \%$ patients were EBC, that is stage IIb or less and $5.6 \%$ patients were in stage IV.

\section{RESULTS}

\begin{tabular}{|c|c|c|}
\hline Presentation & Frequency & Percentage \\
\hline $\begin{array}{c}\text { Isolated lump in } \\
\text { breast }\end{array}$ & 93 & 90 \\
\hline $\begin{array}{c}\text { Fungating/ } \\
\text { ulcerative growth }\end{array}$ & 4 & 4.16 \\
\hline Combination & 5 & 5.2 \\
\hline $\begin{array}{c}\text { Isolated nipple } \\
\text { discharge }\end{array}$ & 1 & 1.04 \\
\hline $\begin{array}{c}\text { Isolated pain in } \\
\text { breast }\end{array}$ & 1 & 1.04 \\
\hline \multicolumn{2}{|c|}{ Total } & $\mathbf{1 0 4}$ \\
\hline \multicolumn{2}{|c|}{ Table 1. Profile of Clinical Presentation } \\
\hline
\end{tabular}

\begin{tabular}{|c|c|}
\hline Duration & Percentage \\
\hline$<15$ days & 2 \\
\hline 15-30 days & 65 \\
\hline 3-6 months & 10 \\
\hline 6 months - 1 year & 15 \\
\hline$>1$ year & 8 \\
\hline Total & $\mathbf{1 0 0}$ \\
\hline Table 2. Duration of Clinical Presentation \\
\hline
\end{tabular}

\begin{tabular}{|c|c|c|}
\hline Histopathology & Ductal & Lobular \\
\hline Invasive & $98(98 \%)$ & $1(1 \%)$ \\
\hline In situ & 0 & $1(1 \%)$ \\
\hline \multicolumn{2}{|c|}{ Table 3. Histopathological Findings } \\
\hline
\end{tabular}

\section{DISCUSSION}

This retrospective analysis was to study the epidemiology of breast cancer at KR Hospital, Mysore. A majority of the patients were in the fourth to sixth decades of their life, which correlated with studies conducted in India and other Asian countries.[4],[5],[6],,[7],[8],[9] However, reports from the western world showed that female breast carcinoma were mostly in the fifth and sixth decade.[10],[11],[12] The incidence of breast carcinoma in males has increased over the time.[13],[14],[15] Unlike from western countries, majority of the patients in this study were from rural setup.[4][16],[15] Indian Council of Medical Research (ICMR) cites that 70\% - 80\% of India's population resides in rural areas.[6] Majority of the patients were of low socioeconomic status. Lump in the breast was the chief complaint in majority of patients with isolated complaints of nipple discharge or pain in the breast.

The incidence of breast carcinoma was more on the left side,[17],[18],[19],[20],[21],[22],[23] possibly due to bulkier left breast and larger volume of breast tissue in upper outer quadrant.[21],[23] This study shows less number of nulliparous patients presenting with breast carcinoma. However, other reports indicate higher incidence of breast carcinoma in nulliparous females.[3],[24],[25]

Majority of the patients had their menarche between the ages of 13 and 16, supporting reports that risk is higher with early onset of menarche.[7],[26],[27],[28] Incidence of breast carcinoma was more in postmenopausal patients and age of menopause was in the range of 41 to 50 years. A similar finding of early age of menopause in Indian females in comparison to their western counterparts has been observed in the past.[29] The earlier published reports also show that the risk of breast carcinoma increases with increasing age of menopause, possibly because the women are exposed to hormones for a longer duration.[27],[28],[30]

For the diagnosis of breast carcinoma, FNAC was done in $86 \%$ of patients which is rapid and cost effective.[31] The use of core needle biopsy (CNB) and vacuum assisted biopsy with mammographic or ultrasonographic guidance is being increasingly used for non-palpable tumours.[31] Mammography is an important tool for breast carcinoma screening between 50 and 70 years, when the breast tissue content decreases and fat content increases. Moreover, mammography is neither cost effective nor easily available in developing countries.

LFTs, abdominal ultrasounds, CT scan and bone scan were done as part of a metastatic workup. Literature also supports that a complete metastatic workup is unnecessary in a majority of the patients with newly diagnosed breast carcinoma, whereas it may be indicated for specific patient categories such as those with stage III disease.[32] Clinical TNM staging is an important clinical parameter of breast carcinoma and surgery is the principle mode of therapy, while chemotherapy, radiotherapy and hormone therapy were used in the adjuvant setting. Popularity of BCS is increasing in the western world.[33],[34],[35],[36],[37],[38] The reasons supporting this theory are earlier diagnosis through mammographic screening, development of image-guided CNB and advent of state-of-the-art Radiotherapy Units.[34] MRM provides good locoregional control and still remains an important tool for managing breast cancer in India. Postoperative morbidity was seen in the form of lymphorrhoea/seroma, flap necrosis and wound infection, 
which was comparable with the reports in the literature.[39],[40],[41],[42],[43],[44][45][46] Neoadjuvant chemotherapy was given in $64 \%$ of the patients for downstaging the disease and a majority of these cases were managed by clinical oncologist.

Our study like all other studies from India and western world indicate that IDC is the most commonly encountered histopathology.[47],[19],[21],[48],[49] A majority of the patients (45\%) present with LABC in accordance with other reports from India.[4] LABC is a relatively uncommon presentation $(5 \%-20 \%)$ in economically developed countries due to better public awareness and availability of medical resources.[50]

\section{CONCLUSION}

The mean age of presentation for breast carcinoma in our centre is a decade earlier compared to west. Hence, early screening clinics and mammography should be considered. Thus, there is a need for developing other cost-effective screening modalities for breast cancer in addition to propagating breast self-examination in masses for early detection. Although, BCS is gaining popularity worldwide, MRM still remains the gold standard for the management of breast carcinoma in the present circumstances in most parts of India. In view of the rising incidence of breast carcinoma and the prevailing controversies in its management, it is recommended that they should preferably be managed by surgical and medical oncologists for improvement in the patient's outcome.

\section{REFERENCES}

[1] Pal SK, Mittal B. Improving cancer care in India: prospects and challenges. Asian Pac J Cancer Prev 2004;5(2):226-8.

[2] Dumitrescu RG, Cotarla I. Understanding breast cancer risk-where do we stand in 2005? J Cell Mol Med 2005;9(1):208-21.

[3] Chandra AB. Problems and prospects of cancer of the breast in India. J Indian Med Assoc 1979;72(2):43-5.

[4] Chopra R. The Indian scene. Journal of Clinical Oncology 2001;19(Suppl 18):S106-S11.

[5] www.icmr.nic.in/ncrp/ncrp_p/cancer_reg.pdf.

[6] Gupta P, Sharma RG, Verma M. Review of breast cancer cases in Jaipur region. J Indian Med Assoc 2002;100(5):282-3, 286-7.

[7] Nouh MA, Ismail $\mathrm{H}$, El-Din $\mathrm{NH}$, et al. Lymph node metastasis in breast carcinoma: clinicopathological correlations in 3747 patients. J Egypt Natl Canc Inst 2004;16(1):50-6.

[8] Malik IA. Clinico-pathological features of breast cancer in Pakistan. J Pak Med Assoc 2002;52(3):100-4.

[9] Chow LW, Ting AC, Cheung KL, et al. Current status of breast cancer in Hong Kong. Chin Med J (Engl) 1997;110(6):474-8.

[10] Hospital Episode Statistics Vol. 2. 1991/92. Department of Health. London: HMSO, 1995.

[11] Anderson WF, Chatterjee N, Ershler WB, et al. Estrogen receptor breast cancer phenotypes in the surveillance, epidemiology and end results database. Breast Cancer Res Treat 2002;76(1):27-36.
[12] El-Tamer MB, Wait RB. Age at presentation of AfricanAmerican and Caucasian breast cancer patients. J Am Coll Surg 1999;188(3):237-40.

[13] Joseph A, Mokbel K. Male breast cancer. Int J Fertil Womens Med 2004;49(5):198-9.

[14] Weiss JR, Moysich KB, Swede H. Epidemiology of male breast cancer. Cancer Epidemiol Biomarkers Prev 2005;14(1):20-6.

[15] Coughlin SS, Thompson TD, Hall HI, et al. Breast and cervical carcinoma screening practices among women in rural and nonrural areas of the United States, 19981999. Cancer 2002;94(11):2801-12.

[16] www.icmr.nic.in/annual/icpo/2003-04/r3.pdf.

[17] Raina V, Bhutani M, Bedi R, et al. Clinical features and prognostic factors of early breast cancer at a major cancer center in North India. Indian J Cancer 2005;42(1):40-5.

[18] Nagpal BL, Singh A, Sehgal RK, et al. Breast cancer in Punjab (a clinicopathological review of 640 cases). J Indian Med Assoc 1980;75(6):113-6.

[19] Hussain MA, Ali S, Tyagi SP, et al. Incidence of cancer breast at Aligarh. J Indian Med Assoc 1994;92(9):2967.

[20] Perkins CI, Hotes J, Kohler BA, et al. Association between breast cancer laterality and tumor location, United States, 1994-1998. Cancer Causes Control 2004;15(7):637-45.

[21] Schwartz SI. Breast. Principles of surgery. $7^{\text {th }}$ edn. New York: McGraw-Hill 1999: p. 564.

[22] Russell RCG, Williams NS, Bulstrode CJK. The breast. In: Bailey and Love's short practice of surgery. $24^{\text {th }}$ edn. Arnold 2004: p. 837.

[23] Lee AH. Why is carcinoma of the breast more frequent in the upper outer quadrant? A case series based on needle core biopsy diagnoses. Breast 2005;14(2):1512.

[24] Kelsey JL, Gammon MD, John EM. Reproductive factors and breast cancer. Epidemiol Rev 1993;15(1):36-47.

[25] Rosner B, Colditz GA, Willett WC. Reproductive Risk factors in a prospective study of breast cancer: the nurses' health study. Am J Epidemiol 1994;139(8):819-35.

[26] Staszewski J. Age at menarche and breast cancer. J Natl Cancer Inst 1971;47(5):935-40.

[27] McPherson K, Steel CM, Dixon JM. ABC of breast diseases. Breast cancer-epidemiology, risk factors and genetics. BMJ 2000;321(7261):624-8.

[28] Alberg AJ, Lam AP, Helzlsouer KJ. Epidemiology, prevention and early detection of breast cancer. Curr Opin Oncol 1999;11(6):435-41.

[29] Bharadwaj JA, Kendurkar SM, Vaidya PR. Age and symptomatology of menopause in Indian women. J Postgrad Med 1983;29(4):218-22.

[30] Trichopoulos D, MacMahon B, Cole P. Menopause and breast cancer risk. J Natl Cancer Inst 1972;48(3):60513.

[31] Oyama T, Koibuchi Y, McKee G. Core needle biopsy (CNB) as a diagnostic method for breast lesions: comparison with fine needle aspiration cytology (FNA). Breast Cancer 2004;11(4):339-42. 
[32] Puglisi F, Follador A, Minisini AM, et al. Baseline staging tests after a new diagnosis of breast cancer: further evidence of their limited indications. Ann Oncol 2005;16(2):263-6.

[33] Singletary SE. New approaches to surgery for breast cancer. Endocr Relat Cancer 2001;8(4):265-86.

[34] Cody HS. Current surgical management of breast cancer. Curr Opin Obstet Gynecol 2002;14(1):45-52.

[35] Winchester DP, Cox JD. Standards for diagnosis and management of invasive breast carcinoma. American College of Radiology. American College of Surgeons. College of American Pathologists. Society of Surgical Oncology. CA Cancer J Clin 1998;48(2):83-107.

[36] Sakorafas GH. Breast cancer surgery--historical evolution, current status and future perspectives. Acta Oncol 2001;40(1):5-18.

[37] Mittra I, Badwe RA, Dinshaw K, et al. Conservative surgery in breast cancer. Indian J Surg 2003;65:32535.

[38] Shenkier T, Weir L, Levine M, et al. Clinical practice guidelines for the care and treatment of breast cancer: 15. Treatment for women with stage III or locally advanced breast cancer. CMAJ 2004;170(6):983-94.

[39] Say CC, Donegan W. A biostatistical evaluation of complications from mastectomy. Surg Gynecol Obstet 1974;138(3):370-6.

[40] Aitken DR, Minton JP. Complications associated with mastectomy. Surg Clin North Am 1983;63(6):1331-52.

[41] Barwell J, Campbell L, Watkins RM, et al. How long should suction drains stay in after breast surgery with axillary dissection? Ann R Coll Surg Engl 1997;79(6):435-7.
[42] Woodworth PA, McBoyle MF, Helmer SD, et al. Seroma formation after breast cancer surgery: incidence and predicting factors. Am Surg 2000;66(5):444-50.

[43] Bryant M, Baum M. Postoperative seroma following mastectomy and axillary dissection. $\mathrm{Br} \quad \mathrm{J}$ Surg 1987;74(12):1187.

[44] Hashemi E, Kaviani A, Najafi M, et al. Seroma formation after surgery for breast cancer. World J Surg Oncol 2004;2:44.

[45] Petrek JA, Peters MM, Nori S, et al. Axillary lymphadenectomy. A prospective, randomized trial of 13 factors influencing drainage, including early or delayed arm mobilization. Arch Surg 1990;125(3):378-82.

[46] van der Wal BC, Butzelaar RM, van der Meij S, et al. Axillary lymph node ratio and total number of removed lymph nodes: predictors of survival in stage I and II breast cancer. Eur J Surg Oncol 2002;28(5):4819.

[47] Goel A, Bhan CM, Srivastava KN. Five year clinico pathological study of breast cancer. Indian J Med Sci 2003;57(8):347-9.

[48] Ahn SH. Clinical characteristics of Korean breast cancer patients in 1998. The Korean Breast Cancer Society. J Korean Med Sci 2000;15(5):569-79.

[49] Harirchi I, Ebrahimi M, Zamani N, et al. Breast cancer in Iran: a review of 903 case records. Public Health 2000;114(2):143-5.

[50] De Vita VT, Hellman S, Rosenberg SA. Cancer of the breast. Cancer principles and practice of oncology. $6^{\text {th }}$ edn. Lippincott Williams and Wilkins 2001: p. 1697. 